\title{
POLITIK HUKUM \\ MEMANFAATKAN WILAYAH UDARA UNTUK KEPENTINGAN PENERBANGAN DI WILAYAH KEDAULATAN N.K.R.I.
}

Oleh :

\author{
Nurlely Darwis, SH, MSi \\ Email : (nurlely.darwis@gmail.com) \\ Dekan Fakultas Hukum - Universitas Suryadarma \\ dan Aktif di Lembaga Konsultasi Bantuan Hukum (LKBH) Fakultas Hukum Universitas Suryadarma
}

\begin{abstract}
Abstrak :
Politik Hukum adalah suatu bidang ilmu yang mempunyai ciri-ciri tertentu, yaitu kegiatan untuk menentukan atau memilih hukum mana yang sesuai untuk mencapai tujuan-tujuan yang dikehendaki oleh masyarakat. Politik Hukum Nasional adalah, Kebijakan dasar penyelenggara negara dalam bidang hukum yang akan, sedang dan telah berlaku, bersumber dari nilai-nilai yang berlaku di masyarakat untuk mencapai tujuan (Republik Indonesia) negara yang dicita-citakan. Dengan berjalannya waktu, pada tahun 1992 UU No. 83 Tahun 1958 diganti dengan UU No. 15 Tahun 1992 tentang Penerbangan selanjutnya dukukukan lagi UU No. 1 Tahun 2009 tentang Penerbangan, yang pada dasarnya UU baru ini telah mengatur masalah penerbangan secara lebih detail dengan jumlah pasal yang lebih banyak. Namun dalam perkembangan waktu NKRI masih memerlukan aturan-aturan dibidang kedirgantaraan untuk menjaga Kedaulanan Negara diwilayah Udara.
\end{abstract}




\section{A. Latar Belakang masalah}

Memahami Politik Hukum pada dasarnya harus melihat antara Politik dan Hukum yang merupakan dua topik ilmu dengan ranah yang berbeda. Hukum pada dasarnya dapat dipelajari dari berbagai sudut pandang, maka lahirnya berbagai disiplin hukum seperti Filsafat Hukum, Ilmu Hukum, Teori Hukum, Sejarah Hukum, Sosiologi Hukum, Perbandingan Hukum, Logika Hukum, Psikologi hukum, dan selanjutnya ada Politik Hukum (Rechtspolitiek). Dalam hal ini Politik Hukum adalah suatu bidang ilmu yang mempunyai ciri-ciri tertentu, yaitu kegiatan untuk menentukan atau memilih hukum mana yang sesuai untuk mencapai tujuan-tujuan yang dikehendaki oleh masyarakat. ${ }^{1}$

Antara kedua topik yang berbeda itu ternyata mempunyai sifat yang saling mempengaruhi seperti halnya, pada tataran realitas kedua topik tersebut ada menunjukkan bahwa hukum dapat mempengaruhi politik atau sebaliknya politik dapat mempengaruhi hukum.

Untuk hal ini Moh. Mahfud MD mengemukakan tentang hal tersebut bahwa terdapat tiga macam jawaban untuk melihat hubungan antara hukum dan politik. Pertama, hukum merupakan determinan politik, kegiatan politik harus tunduk pada hukum, Kedua, pandangan yang melihat bahwa politik determinan atas hukum karena sesungguhnya hukum adalah produk politik yang sarat

${ }^{1}$ Satjipto Rahardjo, Ilmu Hukum; Alumni, Bandung; 1991, hlm 325; Melalui buku Imam Syaukani; A. Ahsin Thohari; Dasar-Dasar Politik Hukum, PT Raja Grafindo Persada, Jakarta; hlm.2. dengan kepentingan dan konfigurasi politik, dan ketiga pandangan yang melihat bahwa hukum dan politik merupakan dua elemen subsistem kemasyarakatan yang seimbang, karena walaupun hukum merupakan produk politik maka ketika ada hukum yang mengatur aktivitas politik maka politikpun harus tunduk pada hukum. ${ }^{2}$

Ketiga macam jawaban di atas adalah struktur teori yang dibangun berdasarkan realitas relasi antara dua sistem tersebut. Pada kesimpulan akhir tulisannya Mahfud MD mengatakan bahwa sesungguhnya politik determinan atas hukum, hukum yang lahir merupakan cerminan konfigurasi politik. Dalam hubungan tarik menarik antara hukum dan politik maka sesungguhnya politik mempunyai energi yang cukup kuat untuk mempengaruhi hukum. Asumsi dasar tadi memperlihatkan bahwa dalam konfigurasi politik yang demokratis maka yang lahir adalah produk hukum yang responsif/populistik, sedangkan konfigurasi politik yang otoriter melahirkan produk hukum yang konservatif /ortodoks dan elitis. ${ }^{3}$

Politik Hukum Nasional, tinjauan awalnya adalah memahami pengertian politik hukum yang diartikan sebagai, "Kebijakan dasar penyelenggara negara dalam bidang hukum yang akan, sedang dan telah berlaku, bersumber dari nilai-nilai yang berlaku di masyarakat untuk mencapai tujuan negara yang dicita-citakan". Jadi Politik Hukum Nasional adalah,

\footnotetext{
${ }^{2}$ Imam Syaukani; A. Ahsin Thohari; DasarDasar Politik Hukum, PT Raji Grafindo Persada, Jakarta; hlm.5 - 8

${ }^{3}$ Ibid.hlm. 7 - 8
} 
Kebijakan dasar penyelenggara negara dalam bidang hukum yang akan, sedang dan telah berlaku, bersumber dari nilai-nilai yang berlaku di masyarakat untuk mencapai tujuan (Republik Indonesia) negara yang dicita-citakan. ${ }^{4}$

Untuk kebijakan dan politik dibidang "Hukum Udara" melalui sejarah penerbangan dapat dilihat adanya pembentukan Undang- Undang Republik Indonesia nomor 4 tahun 1976 tentang perubahan dan penambahan beberapa pasal dalam Kitab Undang - Undang Hukum Pidana/KUHP, berkaitan dengan perluasan berlakunya ketentuan perundang-undangan pidana, tentang Kejahatan Penerbangan, dan Kejahatan Terhadap Sarana / Prasarana Penerbangan.

Dengan berjalannya waktu, pada tahun 1992 Undang-Undang Nomor 83 Tahun 1958 diganti dengan Undang-Undang Nomor 15 Tahun 1992 tentang Penerbangan. Pada tanggal 12 Januari 2009 Presiden Susilo Bambang Yudhoyono mensahkan Undang-Undang Nomor 1 Tahun 2009 tentang Penerbangan, yang pada dasarnya Undang-Undang baru ini telah mengatur masalah penerbangan secara lebih detail. Hal ini terlihat dari keseluruhan UU No. 15 Tahun 1992 terdiri dari 15 bab dan 76 pasal sedangkan UU No. 1 Tahun 2009 terdiri dari 24 bab dan 446 pasal. Dengan jumlah pasal yang lebih banyak, undang-undang yang baru

${ }^{4}$ Ibid. hlm. 58

${ }^{5}$ Pasal.1 poin 2 Undang-Undang No 1 Tahun 2009 tentang Penerbangan. tentunya akan memberikan kepastian hukum secara lebih baik bagi pemerintah, badan usaha, maupun setiap warga negara yang menggunakan jasa penerbangan.

Wilayah Udara adalah wilayah kedaulatan udara di atas wilayah daratan dan perairan Indonesia. ${ }^{5}$ "Keselamatan" Penerbangan adalah suatu keadaan terpenuhinya persyaratan keselamatan dalam pemanfaatan wilayah udara, pesawat udara, bandar udara, angkutan udara, navigasi penerbangan, serta fasilitas penunjang dan fasilitas umum lainnya. ${ }^{6}$ Sedangkan "Keamanan" Penerbangan adalah suatu keadaan yang memberikan perlindungan kepada penerbangan dari tindakan melawan hukum melalui keterpaduan pemanfaatan sumber daya manusia, fasilitas, dan prosedur. ${ }^{7}$

\section{B. Permasalahan}

Untuk penegakan kedaulatan dan hukum diruang Udara nasional, berdasarkan Aeronautical Information Publication (AIP) Indonesia, ditetapkan bahwa area yang menjadi area udara terlarang hanya WRP 23 Balikpapan Flare. Namun demikian, pada kenyataannya ruang udara nasional diatur oleh aturan-aturan internasional yang tidak sesuai dengan kehendak Indonesia sebagai negara kepulauan (ArchipelagicState).

Negara maju seperti Amerika Serikat pada kenyataannya belum meratifikasi Konvensi Hukum Laut Tahun 1982 (United Nations Convention On The Law

\footnotetext{
${ }^{6}$ Pasal 48 Undang-Undang No 1 Tahun 2009 tentang Penerbangan.

${ }^{7}$ Pasal 49 Undang-Undang No 1 Tahun 2009 tentang Penerbangan.
} 
of The Sea/UNCLOS 1982), padahal negara lain sudah banyak yang meratifikasi, sehingga bila Amerika Serikat melintasi perairan dan wilayah udara nasional Indonesia, mereka masih berpedoman kepada aturanaturan yang lama, seperti Traditional Route for Navigatio. Hal ini sering membuat terjadinya benturan dimana berdasarkan aturan lama tersebut pesawat-pesawat Amerika Serikat melintas di atas rute tradisional yang mereka anggap sah dengan alasan bahwa Amerika Serikat belum meratifikasi UNCLOS 1982. Oleh karena itu, untuk kepentingan pertahanan dan keamanan, diperlukan peningkatan status beberapa area udara dari Restricted Area menjadi Prohibited Area, sebagai contoh WRR 1 Madiun dan WRR 11 Malang seharusnya ditingkatkan menjadi Prohibited Area.

Dalam dunia penerbangan dikenal adanya Flight Information Region (FIR) dan jugaUpper Flight Information Region (UIR). FIR dan UIR merupakan wilayah yang penetapannya tidak berdasarkan wilayah teritorial, tetapi ditetapkan berdasarkan kepentingan dan pertimbangan keselamatan penerbangan (safety consideration). Sehubungan dengan masalah kedaulatan Negara di udara, maka penguasaan Air Traffic Control (ATC) oleh Singapura di wilayah Indonesia yaitu di kawasan Kepulauan Riau (Kepri), bukan saja menyebabkan terjadi pelanggaran kedaulatan wilayah udara Negara Kesatuan Republik Indonesia (NKRI), namun

\footnotetext{
${ }^{8}$ Mufti Makarim. A, Strategi Pengelolaan Dan Pertahanan Wilayah Perbatasan Udara
}

juga memberikan implikasi yang sangat luas khususnya terhadap aspek pertahanan udara dan kerugian bidang ekonomi.

Kemungkinan ancaman di wilayah perbatasan, bahwa kondisi saat ini ada kecenderungan isu masalah perbatasan darat dan laut. Hal ini dapat dimaklumi mengingat sejumlah kasus yang menonjol dan mengemuka di media atau terdeteksi secara terbuka adalah yang berhubungan dengan wilayah perbatasan darat dan laut. Bergesernya patok perbatasan, aktivitas ekonomi dan rekrutmen milisi, pelintas gelap dan penyelundupan, pencurian, hingga perdagangan pulau kepada sejumlah pemilik warga negara asing dan penguasaan pulau terluar oleh negara jiran adalah sejumlah isu yang sering muncul di media, menjadi perbincangan hangat dan agenda politik, keamanan dan pertahanan di masyarakat hingga ke level parlemen dan pemerintah. ${ }^{8}$

Struktur dan model ancaman terus berkembang bersamaan dengan perkembangan aktivitas politik, ekonomi dan rekayasa teknologi di berbagai negara. Perkembangan politik dan teknologi kemudian memunculkan sejumlah ancaman kontemporer yang memiliki efek sama kuatnya atau bahkan lebih dari serangan militer seperti embargo ekonomi, embargo udara, operasi mata - mata (surveillance) dengan perangkat satelit, hingga ke penggunaan senjata biologis,

Republik Indonesia : Tantangan Aspek Politik, Yuridis dan Operasional, 2011, hal 24 
terorisme, penyusupan, sabotase dan penyadapan arus komunikasi.

Hal lain yang mempengaruhi minimnya perhatian terhadap wilayah perbatasan udara adalah terbatasnya aktivitas yang diidentifikasi sebagai pelanggaran atau ancaman di wilayah udara misalnya hanya dikaitkan dengan pelanggaran penerbangan atau pemantauan oleh radar negeri tetangga. Sejumlah kasus dan pelanggaran tidak jelas penyelesaiannya, baik yang diberitakan akan diselesaikan melalui jalur hukum maupun diplomasi. Sementara sejumlah ancaman lain mungkin juga akan terjadi, seperti pengintaian, perlintasan benda-benda asing dan pemanfaatan sumber daya alam di udara.

Hal-hal semacam ini tidak dapat dianggap sepele, mengingat wilayah udara merupakan titik strategis untuk mengamati atau memulai suatu tindakan militer yang berakibat fatal terhadap kedaulatan, keselamatan warga negara serta wilayah. Wilayah udara juga mengandung sumber daya alam yang pada suatu saat dapat dimanfaatkan. Walaupun sejumlah arbitrase internasional (dengan merujuk pada kasus yang dianggap melanggar konvensi Chicago 1944 misalnya) dalam kasus - kasus pelanggaran terhadap wilayah udara cenderung mengecewakan hasilnya, namun bukan berarti tidak serius dalam hal menangni masalah yang ada. ${ }^{9}$

${ }^{9}$ Ibid
Undang-undang wilayah negara yang dimiliki oleh Indonesia tidak secara spesifik mengatur tentang ruang udara, mengingat yang disebutkan di dalam undang-undang hanya mengatur tentang wilayah laut dan darat negara Indonesia.

\section{Kajian Teori Hukum Udara}

Masalah status hukum ruang udara diatas wilayah daratan dan perairan suatu negara berdaulat yang digunakan untuk melakukan penerbangan, mulai dibahas secara resmi dalam konferensi Paris 1910 yang berlatar belakang adanya kenyataan banyaknya penerbangan yang berlangsung di Eropa, tanpa memperhatikan kedaulatan negara dibawahnya, karena pada waktu itu belum ada pengaturannya, maka yang terjadi adalah kebebasan tinggal landas dari satu negara dan mendarat dinegara lain tanpa adanya ijin dari negara yang bersangkutan, apalagi pesawat udara dapat digunakan untuk mengangkut militer, mata-mata yang dapat mengancam keamanan nasional negara dibawahnya. ${ }^{10}$

Ruang udara nasional adalah merupakan salah satu sumber daya alam yang terdapat di udara, dan sekaligus merupakan wilayah nasional sebagai wadah atau ruang/media, tempat Negara Kesatuan Republik Indonesia (NKRI) melaksanakan kedaulatan, hak berdaulat dan yurisdiksinya, sesuai dengan ketentuan dalam Konvensi Chicago 1944 tentang Penerbangan Sipil Internasional, dan

10 Martono; Amad Sudiro; Hukum Udara Nasional dan Internasional Publik; PT. Raja Grafindo Persada Jakarta; hal 11. 
juga dalam pasal 4 UU No. 1 tahun 2009,11 tentang Penerbangan. Kewenangan Negara menetapkan batas negara, wilayah dapat diartikan sebagai ruang dimana manusia yang menjadi warga negara atau penduduk negara yang bersangkutan hidup serta menjalankan segala aktifitasnya. Di dalam kondisi dunia yang sekarang ini, sebuah wilayah negara tentunya akan berbatasan dengan wilayah negara lainnya, dan di dalamnya akan banyak terkait aspek yang saling mempengaruhi situasi dan kondisi perbatasan yang bersangkutan. ${ }^{12}$

Perbatasan negara seringkali didefinisikan sebagai garis imajiner di atas permukaan bumi yang memisahkan wilayah satu negara dengan wilayah negara lainnya. Sejauh perbatasan itu diakui secara tegas dengan traktat atau diakui secara umum tanpa pernyataan tegas, maka perbatasan merupakan bagian dari suatu hak negara terhadap wilayah. Dalam rangka menyelenggarakan kedaulatan negara atas wilayah udara nasional, pemerintah mempunyai wewenang dan tanggung jawab pengaturan ruang udara untuk kepentingan pertahanan dan keamanan negara, serta keselamatan penerbangan. Sesuai dengan pasal 66 ayat 1 PP No. 3 Tahun 2001 tentang keamanan dan keselamatan penerbangan, disebutkan bahwa untuk menjamin keselamatan operasi

${ }^{11}$ Pasal 4 UU No. 1 tahun 2009: Undangundang ini berlaku untuk (a). semua kegiatan penggunaan wilayah udara, navigasi penerbangan, pesawat udara, bandar udara, pangkalan udara, angkutan udara, keselamatan dan keamanan penerbangan, serta fasilitas penunjang dan fasilitas umum lain yang terkait, termasuk kelestarian lingkungan di wilayah Negara Kesatuan Republik Indonesia; (b). Semua pesawat udara asing yang penerbangan, ditetapkan Kawasan Udara Terlarang, Kawasan Udara Terbatas (Restricted Area) dan Kawasan Udara Berbahaya (Danger Area).

Kawasan Udara Terlarang adalah ruang udara tertentu di atas daratan dan/atau perairan, di mana pesawat udara dilarang terbang melalui ruang udara tersebut karena pertimbangan pertahanan dan keamanan negara, serta keselamatan penerbangan. Kawasan Udara Terbatas adalah ruang udara tertentu di atas daratan dan/atau perairan, karena pertimbangan pertahanan dan keamanan atau keselamatan penerbangan atau kepentingan umum, berlaku pembatasan penerbangan bagi pesawat udara melalui ruang udara tersebut. Sedangkan Kawasan Udara Berbahaya adalah ruang udara tertentu di atas daratan dan/atau perairan, yang sewaktu-waktu terjadi aktivitas yang membahayakan penerbangan pesawat udara. Pesawat udara Nasional maupun Asing dilarang terbang diatas daerah atau terbatas untuk menjamin keamanan nasional maupun keselamatan penerbangan. Larangan tersebut berlaku umum terhadap pesawat udara manapun juga, tanpa diskriminasi

Penentuan daerah terlarang hanya atas pertimbangan keamanan nasional (nasional security), keselamatan penerbangan (aviation safety) maupun

melakukan kegiatan dari dan/atau ke wilayah Negara Kesatuan Republik Indonesia; dan (c).Semua pesawat udara Indonesia yang berada di luar wilayah Negara Kesatuan Republik Indonesia.

${ }^{12}$ Moh. Kusnardi; Bintan R. Saragih; Ilmu Negara (Unsur-unsur Negara); Gaya Media Pratama, Jakarta; 1993, hlm.105 
kemakmuran nasional (national prosperty), tidak boleh menentukan daerah terlarang atas pertimbangan politik suatu Negara. Bilamana pesawat udara asing ataupun nasional terlanjur berada di daerah terlarang, pesawat udara tersebut segera meninggalkan daerah terlarang. Tetapi jika mereka menyadari posisinya, pesawat udara tersebut dikejar dan dipaksa untuk mendarat dibandar udara atau pangkalan udara yang berdekatan.

Terhadap pelanggaran wilayah udara Republik Indonesia dan atau kawasan udara terlarang oleh pesawat udara sipil, dilaksanakan penegakan hukum yang harus menjamin keselamatan dan keamanan awak pesawat, penumpang dan pesawat udara. Penegakan hukum terhadap pelanggaran wilayah udara dan atau kawasan udara terlarang sebagaimana dimaksud di atas, dilakukan oleh Tentara Nasional Indonesia.

\section{Kedaulatan Atas Wilayah Udara}

Negara terdiri dari beberapa unsur yaitu wilayah, penduduk, pemerintah, dan kedaulatan. ${ }^{13}$ Dalam ilmu Negara telah dijelaskan bahwa kedaulatan negara merupakan bagian dari kekuasaan Negara untuk memaksa semua penduduk agar mentaati undang-undang dan peraturanperaturannya (kedaulatan kedalaminternal sovereignty).

Disamping itu Negara mempertahankan kemerdekaannya terhadap serangan-serangan dari negara lain dan mempertahankan kedaulatan ke luar (external sovereignty).

Deklarasi Djuanda yang dicetuskan pada Desember tahun 1957 oleh Perdana Menteri Indonesia pada saat itu, Djuanda Kartawidjaja, adalah deklarasi yang menyatakan kepada dunia, bahwa laut Indonesia adalah termasuk laut sekitar, di antara dan di dalam kepulauan Indonesia menjadi satu kesatuan wilayah NKRI, dan ini merupakan wilayah kedaulatan NKRI. Deklarasi Djuanda menyatakan bahwa Indonesia menganut prinsip-prinsip negara kepulauan (Archipelagic State) yang pada saat itu mendapat pertentangan besar dari beberapa negara, sehingga laut-laut antar pulau juga merupakan wilayah Republik Indonesia dan bukan kawasan bebas. Deklarasi Djuanda selanjutnya diresmikan menjadi Undang-undang No.4/PRP/1960 tentang Perairan Indonesia. ${ }^{14}$

Setelah melalui perjuangan yang penjang, deklarasi ini pada tahun 1982 akhirnya dapat diterima dan ditetapkan dalam konvensi hukum laut PBB ke-III Tahun 1982 (United Nations Convention On The Law of The Sea/UNCLOS 1982). Selanjutnya delarasi ini dipertegas kembali dengan Undang-undang Nomor 17 Tahun 1985 tentang pengesahan UNCLOS 1982 bahwa Indonesia adalah negara kepulauan dan isi dari Deklarasi Juanda yang ditulis pada 13 Desember 1957, menyatakan: ${ }^{15}$
${ }^{13}$ Moh. Kusnardi; Bintan R. Saragih; Ilmu Negara (Unsur-unsur Negara); Gaya Media Pratama, Jakarta; 1993, hlm.122

\footnotetext{
${ }^{14}$ Joko Subagyo; Hukum LAut Indonesia; Rineka CIpta, 2009, hlm. 6

${ }^{15} \mathrm{I} b i d$
} 
1. Bahwa Indonesia menyatakan sebagai negara kepulauan yang mempunyai corak tersendiri;

2. Bahwa sejak dahulu kala kepulauan nusantara ini sudah merupakan satu kesatuan;

3. Ketentuan ordonansi 1939 tentang Ordonansi, dapat memecah belah keutuhan wilayah Indonesia dari deklarasi tersebut mengandung suatu tujuan :

a. Untuk mewujudkan bentuk wilayah Kesatuan Republik Indonesia yang utuh dan bulat;

b. Untuk menentukan batas-batas wilayah NKRI, sesuai dengan azas negara Kepulauan;

c. Untuk mengatur lalu lintas damai pelayaran yang lebih menjamin keamanan dan keselamatan NKRI;

Dalam pengaturan secara internasional, ruang udara diatur dalam Konvensi Chicago 1944, dimana Indonesia telah mematuhi (adhere) sejak 27 April 1950 dengan Surat Duta Besar Republik Indonesia, yang mengakui adanya kedaulatan setiap Negara yang penuh dan eksklusif di atas wilayah ruang udaranya. Hukum internasional mengenal beberapa cara bagi suatu Negara diantaranya adalah ratifikasi. Dalam hal ini suatu instrument perjanjian internasional yang telah ditandatangani dan disepakati oleh Negara-negara yang terlibat dalam suatu perundingan umumnya masih membutuhkan adanya penegasan kembali, yang dilakukan melalui lembaga ratifikasi.

Setelah dilakukan tindakan ratifikasi, naskah perjanjian internasional tersebut dapat dikirim kembali ke tempat penyimpanan (depository) naskah perjanjian sebagai bukti keterkaitan suatu Negara terhadap perjanjian internasional tersebut. Namun hal ini yang perlu dicatat bahwa tidak seluruh perjanjian internasional membutuhkan ratifikasi untuk dapat diberlakukan. Karena itu ada beberapa ahli menyatakan bahwa ratifikasi hanya sekedar memberikan pernyataan formal keterkaitan terhadap suatu perjanjian internasional.

Demikian pula terhadap Konvensi Chicago 1944, Indonesia menundukan diri pada Konvensi Chicago 1944 hanya dengan Surat Duta Besar RI berupa keikutsertaan Indonesia sebagai anggota ICOA dan tidak ada ratifikasi terhadap Konvensi Chicago 1944, dengan demikian Indonesia dianggap telah turut serta sebagai pihak pada perjanjian internasional, yakni Konvensi Chicago 1944.

Konvensi Chicago 1944 sudah dipandang oleh banyak ahli hukum sebagai "magna charta" atau sumber hukum udara internasional, dimana hukum udara dapat terbentuk setelah melewati perkembangan sejarah dan perdebatan yang sangat panjang. Secara umum hukum udara diklasifikasikan dalam dua istilah yaitu: Hukum Udara Publik dan Hukum Udara Sipil (International Public/Civil Air Law), namun ada juga yang menyebutnya dengan istilah International Public/Civil Aeronautical Law.

Lebih spesifik terkait pengelolaan dan pertahanan di wilayah perbatasan 
udara, permasalahan yang bersifat teknis juga terjadi, seperti diketahui bahwa klaim wilayah perbatasan udara Indonesia mengkuti garis lurus vertikal wilayah perbatasan darat dan perairan atau konsep perbatasan tiga dimensi. Akibatnya penentuan wilayah perbatasan udara terutama di perairan mengikuti konfigurasi perbatasan yang ada dan terpecah-pecah. Akibatnya pemantauan terhadap perbatasan udara menjadi sulit karena factor kesulitan mengetahui secara pasti batasan antara ruang udara Indonesia dan ruang udara bebas (di atas wilayah perairan internasional).

Undang-undang Nomor 1 tahun 2009, terdapat berbagai ketentuan pidana, pelanggaran dan kejahatan. Ketentuan ini meliputi Pelanggaran Wilayah Udara, produksi pesawat udara, pendaftaran pesawat udara, perubahan tanda pendaftaran, pengoperasian pesawat udara, sertifikat operator pesawaat udara untuk angkutan udara niaga dan lainnya.

1. Berkaitan dengan pelanggaran Wilayah Udara diatur dalam pasal 401:

"Setiap orang yang mengoperasikan pesawat udara Indonesia atau pesawat udara asing yang memasuki kawasan udara terlarang dipidana dengan pidana penjara paling lama 8 (delapan) tahun dan denda paling banyak Rp. 500.000.000 (lima ratus juta rupiah)" dan Pasal 402: "Orang yang mengoperasikan pesawat udara Indonesia atau asing yang memasuki kawasan udara yang hanya dapat digunakan untuk penerbangan pesawat udara negara dipidana dengan pidana penjara paling lama 8 (delapan ) tahun dan denda paling banyak Rp. 500.000.000 (lima ratus juta rupiah)".

2. Berkaitan dengan terbang diluar jalur, diatur dalam pasal 411 dan pasal 53: "setiap orang dengan sengaja menerbangkan atau mengoperasikan pesawat udara diluar jalur yang ditentukan, terbang tidak membawa peralatan keselamatan, dan terbang diatas kawasan udara terlarang yang membahayakan keselamatan pesawat udara, penumpang, dan barang atau penduduk, mrugikan harta benda milik orang lain dipidana dengan pidana penjara paling lama 2 (dua) tahun dan denda paling banyak Rp. 500.000.000 (liamratus juta rupiah)". Disamping ancaman pidana tersebut, orang yang dengan sengaja menerbangkan atau menoperasikan pesawat udara diluar jalur yang ditentukan, terbang tidak membawa peralatan keselamatan dan terbang diatas kawasan udara terlarang juga dikenakan sanksi administrasi yang berupa pembekuan sertifikat dan pencabutan sertifikat.

\section{E. Peran TNI Angkatan Udara}

Penegakkan hukum adalah merupakan bagian dari upaya pertahankan kedaulatan negara. Sebagai negara yang berdaulat, pemerintah Indonesia menetapkan seperangkat aturan hukum untuk mengatur, mengendalikan dan menegakkan 
hukum di wilayah udara yang berada dibawah yuridiksi Indonesia. Dalam penetapan perangkat hukum tersebut selain berpedoman pada kepentingan nasional bangsa Indonesia, juga memperhatikan kaidah yang diatur dalam hukum internasional. Institusi yang berwenang sebagai penegak kedaulatan udara adalah Tentara Nasional Indonesia Angkatan Udara (TNI-AU). Hal itu tertuang dalam Undang-Undang no. 20 tahun 1982 tentang pokok-pokok pertahanan dan keamanan (hankam), pada pasal 30 ayat 3 disebutkan bahwa TNI-AU bertugas selalu penegak kedaulatan di udara dan mempertahankan keutuhan wilayah dirgantara nasional.

Pasal 10 UU Nomor 34 Tahun 2004 tentang Tentara Nasional Indonesia/ TNI, Angkatan Udara bertugas antara lain:

1. Melaksanakan tugas TNI matra udara di bidang pertahanan;

2. Menegakkan hukum dan menjaga keamanan di wilayah udara Yuridiksi Nasional sesuai dengan ketentuan hukum nasional dan hukum internasional yang telah diratifikasi;

3. Melaksanakan tugas TNI dalam pembangunan dan pengembangan kekuatan matra udara, dan melaksanakan pemberdayaan wilayah pertahanan udara.

Berdasarkan ketentuan tersebut diatas, TNI Angkatan Udara diberi wewenang dan tanggung jawab dalam penegakan kedaulatan dan hukum terhadap pelanggaran di wilayah udara, termasuk kawasan udara terlarang, terbatas dan daerah berbahaya sesuai dengan tugas pokoknya.

Untuk mengimplementasikan pelaksanaan tugas pokok dan funsinya itu dibutuhkan peran Komando Pertahanan Udara Nasional (Kohanudnas). Karena Kohanudnas memiliki kemampuan deteksi, identifikasi dan penindakan terhadap seluruh wahana udara yang melakukan pelanggaran terhadap wilayah udara Republik Indonesia. Hakekat Operasi Pertahanan Udara adalah merupakan kegiatan upaya mempertahankan kedaulatan wilayah nasional terhadap setiap ancaman yang menggunakan media udara.

Undang - undang RI. No. 3 Tahun 2002 tentang Pertahanan Negara disebutkan bahwa: "Pertahanan Negara bertujuan untuk menjaga dan melindungi kedaulatan negara, keuntuhan wilayah Negara Kesatuan Republik Indonesia (NKRI) serta keselamatan segenap bangsa dari segala bentuk ancaman". Upaya untuk mewujudkan pengakuan kedaulatan di wilayah teritorial Negara kepulauan tidak terlepas dari prinsip Negara kepulauan (archipelago principles) yang ada dalam dokumen hasil pembicaraan empat negara (Fiji, Filipina, Indonesia, Mauritius) dalam sidang United National Seabed Committee pada tahun 1972 di New York, khususnya prinsip kedua yang menyatakan, "Negara kepulauan berdaulat atas perairan yang terdapat di dalam garis pangkal lurus yang ditarik antara pulau-pulau terluar. Kedaulatan ini tidak saja meliputi perairan tetapi mencakup juga 
dasar laut (seabed) dan tanah dibawahnya (subsoil) serta ruang udara di atas perairan kepulauan". ${ }^{16}$

Amandemen UUD 1945 Bab IX A tentang Wilayah Negara, Pasal 25A tercantum Negara Kesatuan Republik Indonesia adalah sebuah negara kepulauan yang berciri Nusantara dengan wilayah yang batas-batas dan hak-haknya ditetapkan dengan undang-undang. $\mathrm{Di}$ sini jelas disebutkan bahwa NKRI adalah negara kepulauan berwawasan nusantara, sehingga batas wilayah di laut harus mengacu pada UNCLOS (United Nations Convension on the Law of the Sea) 82/ HUKLA (Hukum laut) 82 yang kemudian diratifikasi dengan Undang-undang Nomor 17 Tahun 1985.

Dampak dari ratifikasi Unclos ini adalah keharusan Indonesia untuk menetapkan Batas Laut Teritorial (Batas Laut Wilayah), Batas Zone Ekonomi Ekslusif (ZEE) dan Batas Landas Kontinen, Negara kepulauan yang memiliki sekitar 17.506 buah pulau dan $2 / 3$ wilayahnya berupa lautan. Dari 17.506 pulau tersebut terdapat pulau-pulau terluar yang menjadi batas langsung Indonesia dengan negara tetangga. Negara Kesatuan Republik Indonesia (NKRI) merupakan negara kepulauan yang terbentang dari $94^{\circ} 58^{\prime} 21^{\prime \prime} \mathrm{BT}-141^{\circ} 01^{\prime}$ $10^{\prime \prime} \mathrm{BT}$ dan $6^{\circ} 04^{\prime} 30^{\prime \prime} \mathrm{LU}-11^{\circ} 00^{\prime} 36^{\prime \prime}$ LS memiliki wilayah teritorial meliputi: ${ }^{17}$

${ }^{16}$ Mochtar Kusumaatmaja, Konsepsi Hukum Negara Nusantara pada Konferensi Hukum Laut III, Pusat Studi Wawasan Nusantara, Hukum dan Pembangunan \& PT. Alumni, Bandung, 2003, hlm. 5-8.
1. Wilayah daratan (Land Territory), Kedaulatan negara RI utuh dan penuh diruang udara diatas wilayah daratan RI dan pemerintah RI mempunyai kedaulatan yang bersifat mutlak dan penuh, tidak mengenal perkecualian

2. Perairan Kepulauan (Archipelago Waters), Perairan yang berada disebelah dalam garis pangkal kepulauan negara RI tanpa memperhatikan kedalaman atau jaraknya dari pantai.

3. Laut Teritorial (Territorial Sea), Dengan jarak 12 Mil laut diukur dari garis pangkal kepulauan RI merentang lurus kearah luar.

Disamping wilayah territorial, NKRI juga memiliki wilayah yurisdiksi diluar wilayah territorial, yang meliputi $:^{18}$

1. Zona Tambahan (Contiguous Zone), Letaknya merentang bersebelahan dengan Laut Territorial dengan lebar tidak melebihi 24 mil laut diukur dari garis pangkal kepulauan dari mana lebar laut territorial RI diukur

2. Zona Ekonomi Eksklusif (Exclusif Economic Zone) Wilayah laut dengan lebar tidak melebihi 200 mil laut diukur dari garis pangkal kepulauan darimana lebar laut territorial RI diukur. Ruang udara diatas ZEE Indonesia yang berada diluar laut territorial RI bebas dipergunakan oleh pesawat udara

www.google.co.id;www.geomatika.its.ac.id/lang/ar chives $/ 774 ; 13$ juli 2015 
asing dengan syarat bahwa penerbangannya tidak melanggar hak-hak RI yang terdapat dalam ZEE RI.

3. Landas Kontinen (Continent Shelf), Merupakan kelanjutan alamiah wilayah daratan dibawah laut hingga tepian luar kontinen yang lebarnya tidak boleh melebihi 350 mil laut yang diukur dari garis dasar/pangkal laut territorial jika diluar 200 mil laut masih terdapat daerah dasar laut yang merupakan kelanjutan alamiah dari wilayah daratan dan jika memenuhi kriteria kedalaman sedimentasi yang ditetapkan dalam konvensi.

Wilayah Ruang Udara Indonesia diatas Alur Laut Kepulauan Indonesia telah ditentukan alur laut (Sea Lanes) dan jalur udara (Air Route) diatasnya untuk koridor bagi kapal laut dan pesawat terbang asing yang akan melewati perairan Indonesia, dan Indonesia telah menetapkan ALKI menjadi 3 (ALKI I, ALKI II dan ALKI III) dengan rute sebagai mana dijelaskan terdahulu.

Procedure interception of civil aircraft dalam menjaga kedaulatan dan keamanan di wilayah ruang udara indonesia, bahwa setiap negara memiliki panduan/aturan dalam melaksanakan penerbangannya. Hal ini dimaksudkan untuk membantu baik bagi pilot dalam membawa pesawatnya maupun operator penerbangan dalam melayani suatu penerbangan. Panduan / aturan penerbangan tersebut terdapat dalam AIP yang dimiliki oleh setiap bandar udara baik sipil maupun militer. Namun prosedur terhadap pesawat sipil dan militer tentunya ada beberapa hal khusus yang berbeda berkaitan dengan fungsi dan tugas dari pesawat tersebut yaitu untuk pesawat sipil berfungsi sebagai pengangkut massal atau cargo dan pesawat militer khususnya pesawat tempur berfungsi sebagai alat keamanan negara dalam menangani gangguan keamanan di udara untuk menjaga kedaulatan negara.

Sebagai perwujudan penegakan kedaulatan di udara, setiap oknum yang melakuan pelanggaran atau tidak kejahatan di wilayah yuridiksi suatu negera, diberikan sanksi sesuai dengan perundangan yang berlaku di negara dimana pelanggaran itu dilakukan. Bagi negara RI prosedur pemberian sanksi, jika menyangkut perbuatan pidana akan diproses sesuai dengan Kitab Undang-Undang Hukum Acara Pidana (KUHAP) yaitu UU No. 8 tahun 1981 dengan sanksi pidana atau denda tertentu (UU No 1 tahun 2009 tentang Penerbangan). Sedangkan jika menyangkut persoalan perdata akan diselesaikan dengan Hukum Acara Perdata, dengan pembebanan ganti rugi (Liability) sesuai dengan peraturan hukum yang berlaku di Indonesia.

\section{F. Kendala Prinsip Kedaulatan Atas Ruang Udara Nasional.}

Salah satu aspek yang perlu diperhatikan dalam pemanfaatan ruang udara beserta sumber daya didalamnya adalah masalah yurisdiksi. Prinsip-prinsip dalam yurisdiksi adalah prinsip teritorial, nasional, personalitas pasif, perlindungan atau keamanan, universalitas, dan kejahatan menurut 
kriteria hukum yang berlaku. Dalam hubungan dengan yurisdiksi negara di ruang udara, sangat erat hubungannya dengan penegakkan hukum di ruang udara tersebut. Dengan adanya yurisdiksi, negara yang tersangkutan mempunyai wewenang dan tanggung jawab di udara untuk melaksanakan penegakkan hukum di ruang udara.

Berkenaan dengan wewenang dan tanggung jawab negara melaksanakan penegakkan hukum di ruang udara tidak terlepas dari muatan Pasal 33 UUD 1945 ayat (3) yang menyatakan, bahwa "bumi, air dan kekayaan alam yang terkandung di dalamnya dikuasai oleh negara dan dipergunakan untuk sebesar - besarnya kemakmuran rakyat". Atas dasar ketentuan tersebut, maka lahir "hak menguasai oleh negara" atas sumber daya alam yang ada di bumi, air dan kekayaan alam yang terkandung di dalamnya (termasuk udara) dan penguasaan tersebut memberikan kewajiban kepada negara untuk digunakan untuk sebesar-besarnya kemakmuran rakyat. Makna dari Pasal 33 ayat (3) UUD 1945 tersebut bahwa ruang udara sebagaimana penjelasan sebelumnya merupakan sumber daya alam yang dikuasai negara. Istilah "dikuasai" bukan berarti "dimiliki" oleh negara, melainkan memberikan arti kewenangan sebagai organisasi atau lembaga negara untuk mengatur dan mengawasi penggunannya untuk sebesar-besarnya kemakmuran rakyat.

Sesuai Konvensi Chicago Tahun 1944, dalam Pasal 1 dinyatakan bahwa setiap negara mempunyai kedaulatan yang utuh dan penuh (complete and exclusive souvereignity) atas ruang udara atas wilayah kedaulatannya. Dari Pasal tersebut memberikan pandangan bahwa perwujudan dari kedaulatan yang penuh dan utuh atas ruang udara di atas wilayah teritorial, adalah:

(1) Setiap negara berhak mengelola dan mengendalikan secara penuh dan utuh atas ruang udara nasionalnya;

(2) Tidak satupun kegiatan atau usaha di ruang udara nasional tanpa mendapatkan izin terlebih dahulu atau sebagaimana telah diatur dalam suatu perjanjian udara antara negara dengan negara lain baik secara bilateral maupun multilateral.

Secara yuridis formal wilayah kedaulatan atas ruang udara nasional belum ada peraturan perundangundangan yang mengatur secara holistik, sampai dikeluarkannya perjanjian atau konvensi Hukum Laut PBB Tahun 1982. ${ }^{19}$

Sejak ditetapkannya konvensi tersebut sebagai hukum internasional dan telah diratifikasi oleh Pemerintah dengan Undang-undang Nomor 17 Tahun 1985, menyebabkan negara Indonesia sebagai negara kepulauan memiliki kewajiban menyediakan Alur Laut Kepulauan Indonesia (ALKI) (archipelagic sea lane passages) yang merupakan jalur lintas damai bagi kapal-kapal asing. Hal tersebut juga berlaku pada wilayah udara di atas alur laut tersebut. Meskipun demikian, pemberlakuan ketentuan tersebut 
belum ada kesepakatan antara International Maritime Organization (IMO) dan International Civil Aviation Organization (ICAO), akibatnya belum ada ketentuan adanya pesawat udara yang mengikuti alur laut tersebut.

Undang-undang lain yang terkait dengan wilayah kedaulatan adalah UU Nomor 5 Tahun 1983 tentang Zona Ekonomi Eksklusif Indonesia. Dalam undang-undang tersebut secara umum dinyatakan bahwa wilayah perairan Indonesia juga mencakup Zona Ekonomi Eksklusif (ZEE) yaitu jalur di luar dan berbatasan dengan laut wilayah sebagaimana ditetapkan dalam UU Nomor 6 Tahun 1996 yang meliputi dasar laut, tanah dibawahnya dan air di atasnya dengan batas terluar 200 (dua ratus) mil laut diukur dari garis pangkal.

Dari uraian di atas, bahwa batas wilayah kedaulatan atas ruang udara nasional belum di atur dalam peraturan perundang-undangan yang ada, bahwa undang-undang hanya menetapkan Indonesia mempunyai wilayah kedaulatan atas ruang udara nasional sebagaimana ditetapkan dalam Pasal 4 dan Pasal 5 UU No. 15 Tahun 1992 tentang Penerbangan.

Kegiatan penerbangan merupakan salah satu wujud kegiatan dan atau usaha terhadap wilayah kedaulatan atas wilayah udara yang diberi wewenang dan tanggung jawab kepada Pemerintah sebagaimana ditetapkan dalam Pasal 5 UU No. 15 Tahun 1992, bahwa dalam rangka penyelenggaraan kedaulatan negara atas wilayah udara Republik Indonesia Pemerintah melaksanakan wewenang dan tanggung jawab pengaturan ruang udara untuk kepentingan pertahanan dan keamanan negara, penerbangan dan ekonomi nasional.

Dalam penjelasan Pasal 5 disebutkan, "wilayah udara yang berupa ruang udara di atas wilayah daratan dan perairan Republik Indonesia merupakan kekayaan nasional sehingga harus dimanfaatkan bagi sebesar-besarnya kepentingan rakyat, bangsa, dan negara. Bentuk lain wujud dari penyelenggaraan kedaulatan atas wilayah udara nasional Indonesia", adalah penegakan hukum terhadap pelanggaran pesawat udara yang terbang pada kawasan terlarang baik nasional maupun asing sebagaimana ditetapkan dalam Pasal 6 ayat (2) UU No. 15 Tahun 1992, bahwa pesawat udara Indonesia atau pesawat udara asing dilarang terbang melalui kawasan udara terlarang, dan terhadap pesawat udara yang melanggar larangan dimaksud dapat dipaksa untuk mendarat di pangkalan udara atau bandara udara di dalam wilayah Republik Indonesia.

Dalam penjelasannya dinyatakan, bahwa kewenangan menetapkan kawasan udara terlarang merupakan kewenangan dari setiap negara berdaulat untuk mengatur penggunaan wilayah udaranya, dalam rangka pertahanan dan keamanan negara dan keselamatan penerbangan. Lebih jauh dalam penjelasan pasal tersebut dinyatakan, kawasan udara terlarang terdiri atas kawasan udara terlarang yang larangannya bersifat tetap (prohibited area) karena pertimbangan pertahanan dan keamanan negara serta keselamatan penerbangan, dan kawasan udara terlarang yang bersifat 
terbatas (restricted area) karena pertimbangan pertahanan dan keamanan atau keselamatan penerbangan atas kepentingan umum, misalnya pembatasan ketinggian terbang, pembatasan waktu operasi, dan lain-lain. Meskipun diatur pelarangan terbang di kawasan udara terlarang dalam Undang-undang tersebut, namun tidak diatur secara tegas wewenang dan tanggung jawab terhadap penenggakan hukum di kawasan udara tersebut. ${ }^{20}$

Wujud dari bentuk wilayah kedaulatan atas ruang udara nasional selain pelarangan di kawasan udara terlarang tersebut diatas, juga terdapat pelarangan lain yaitu perekaman dari udara menggunakan pesawat udara sebagaimana ditetapkan dalam Pasal 17 ayat (1) Undang-undang Nomor 15 Tahun 1992, bahwa dilarang melakukan perekaman dari udara dengan menggunakan pesawat udara kecuali atas izin Pemerintah. Pelarangan tersebut dimaksudkan untuk kepentingan pertahanan dan keamanan negara. Dari beberapa ketentuan pelarangan sebagaimana diatur dalam UU No. 15 Tahun 1992 sebagai wujud pengakuan wilayah kedaulatan atas ruang udara nasional, tetapi tidak mengatur wewenang dan tanggung jawab penegakkan hukum di ruang udara nasional sebagai wilayah kedaulatan diudara dan dikawasan udara terlarang.

Dengan ditetapkannya batas ketinggian wilayah kedaulatan atas ruang udara nasional 110 (seratus sepuluh) $\mathrm{km}$ dari permukaan laut, maka urgensi dari undang-undang pengelolaan ruang udara nasional menjadi penting sesuai dengan amanat Pasal 25 A UUD 1945 dinyatakan, bahwa Negara Kesatuan Republik Indonesia adalah sebuah negara kepulauan yang berciri nusantara dengan wilayah yang batas-batas dan hak-haknya ditetapkan dengan undang - undang.

\section{G. Kesimpulan}

Negara memiliki yurisdiksi wilayah udara selain wilayah darat dan laut, sebagai klaim teritorial atas ruang udara diatasnya. Dalam hubungannya dengan ruang udara sebagai salah satu unsur wilayah dalam suatu negara, Pasal 1 Konvensi Paris 1919 menyatakan "Negara-negara pihak mengakui bahwa tiap-tiap negara mempunyai kedaulatan penuh dan eksklusif atas ruang udara yang terdapat diatas wilayahnya". Konvensi Chicago 1944 mengambil secara integral prinsip yang terdapat dalam Konvensi Paris 1919. Kedua konvensi tersebut dengan sengaja menjelaskan bahwa wilayah negara juga terdiri dari laut wilayahnya yang berdekatan. Hal ini juga dinyatakan dalam pasal 2 Konvensi Jenewa mengenai laut wilayah dan oleh pasal 2 ayat (2) Konvensi PBB tentang Hukum Laut 1982 sebagaimana telah disinggung didepan. Ketentuan-ketentuan yang berlaku tentang navigasi udara, termasuk udara diatas laut wilayah, sama sekali berbeda dengan ketentuanketentuan yang mengatur pelayaran maritim. Terutama tidak ada normanorma hukum kebiasaan yang

${ }^{20}$ Ibid. ;Angkasasena.blogspot.com 
memperbolehkan secara bebas lintas terbang di atas wilayah negara, yang disamakan dengan prinsip hak lintas damai (right of passage innocent) di perairan nasional suatu negara.

Satu-satunya pengecualian adalah mengenai lintas udara diselat-selat internasional tertentu dan alur laut Kepulauan, sebagai akibatnya, kecuali kalau ada kesepakatan konvensional lain. Suatu negara bebas untuk mengatur dan bahkan melarang pesawat asing terbang diatas wilayahnya dan tiap-tiap penerbangan yang tidak diizinkan merupakan pelanggaran terhadap kedaulatan teritorial negara yang berada dibawahnya.

Masalah pengawasan dan keamanan lalu lintas udara dan pengamanan atas pesawat-pewasat udara merupakan aspek sangat penting dalam pengaturan hukum yang dibuat oleh negara-negara. Untuk memperkuat ketentuan-ketentuan yang terdapat dalam konvensi, negara-negara sering membuat kesepakatan bilateral atau regional dibidang kerjasama pengawasan ataupun keamanan.

Masalah penetapan garis batas antara ruang udara dan ruang angkasa, adalah suatu kenyataan bahwa Negara-negara di dunia ini mengakui perlu adanya penegasan mengenai perbatasan antara ruang udara yang berada dalam kedaulatan penuh suatu Negara dan ruang angkasa yang bebas dan hanya digunakan untuk kepentingan kemanusiaan dan perdamaian. Status hukum pesawat angkasa bolak-balik ini telah mulai dipersoalkan sejak tahun 1974, pada saat pembuatan konvensi tentang registrasi bendabenda yang diluncurkan ke ruang angkasa (registration convention 1974).

Para ahli hukum pada umumnya berpendapat bahwa "space shuttle" mempunyai status hukum pesawat angkasa, bukan sebagai pesawat udara, karenanya tunduk pada ketentuanketentuan hukum angkasa dan tidak pada konvensi Chicago 1944 serta peraturan-peraturan hukum udara lainnya. Teori ini lahir untuk memperkuat argumentasi klaim batas kedaulatan sebuah negara atas ruang udara sesuai dengan prinsip-prinsip hukum udara internasional. Namun teori ini juga dapat diterapkan untuk mengetahui batas ketinggian jelajah pesawat udara komersial. Sehingga apabila terjadi kecelakaan pesawat udara. Dapat dipakai sebagai dasar argumentasi.

Beragam kasus terkait keterbatasan TNI AU memantau penerbangan gelap dan menggunakan landasan udara di seluruh wilayah RI, kelemahan-kelemahan ATC Bandar udara dan ketiadaan integrasi kerja radar sipil dan militer dalam sistem Transmission Data Air Situation (TDAS) hingga strategi diplomasi internasional terkait pemanfaatan ruang udara dan antariksa RI hendaknya menjadi pelajaran untuk meningkatkan kapasitas pertahanan di wilayah perbatasan udara NKRI.

Pengelolaan dan pertahanan wilayah udara yang belum maksimal hendaknya juga menjadi prioritas proyeksi strategis kedepan terkait rencana pembangunan dan 
pemanfaatan sumber daya alam untuk kesejahteraan bangsa Indonesia. Diharapkan juga konsepsi pengelolaan dan pertahanan wilayah perbatasan udara merupakan konsepsi yang integral dengan penanganan wilayah perbatasan darat dan laut serta menjadi bagian dari agenda pembangunan lainnya seperti pengentasan wilayah tertinggal dan pemanfaatan sumber daya yang tersedia untuk pembangunan nasional. Tanpa kedua pandangan ini, maka cita-cita luhur untuk mengamankan dan mengelola seluruh wilayah perbatasan darat, laut dan udara kita hanya akan menjadi konsep dan segala upaya yang dilakukan berjalan di tempat.

\section{DAFTAR PUSTAKA}

Buku:

Burhan Ashofa, Metode Penelitian Hukum,

(Jakarta: PT. Rineka Cipta. 1988).

Chappy Hakim dari Segara Ke Angkasa,

Sebuat Otobiografi; PT Buana Ilmu

Poluler; Jakarta Pelangi

Dirgantara;

Kompas, Jakarta; 2010

Imam Syaukani; A. Ahsin Thohari; Dasar-

Dasar Politik Hukum, PT Raji

Grafindo Persada, Jakarta.

Martono; Amad Sudiro;Hukum Udara

Nasional dan Internasional Publik;

PT. Raja Grafindo Persada Jakarta. . Hukum Angkutan Udara, berdasarkan UU RI No. 1 tahun 2009; Rajawali Pers PT. Raja Grafindo Persada Jakarta.

\section{P. Joko Subagyo Hukum Laut} Indonesia; Rineka Cipta; 2009

T. Tarigas Sibero; 50 Tahun Hercules; Dinas Penerangan TNI Angkatan Udara; Jakarta;
M. Abriyanto, dkk Menghias cakrawala Angkasa, Otobiografi Wage Mulyono; Q.Communication, Jakarta 2004.

Mochtar Kusumaatmaja, Konsepsi Hukum Negara Nusantara pada Konferensi Hukum Laut III, Pusat Studi Wawasan Nusantara, Hukum dan Pembangunan \& PT. Alumni, Bandung, 2003.

Moh. Kusnardi; Bintan R. Saragih; Ilmu Negara (Unsur-unsur Negara); Gaya Media Pratama, Jakarta; 1993.

Mufti Makarim. A, Strategi Pengelolaan Dan Pertahanan Wilayah Perbatasan Udara Republik Indonesia : Tantangan Aspek Politik, Yuridis dan Operasional, 2011.

Satjipto Rahardjo, Ilmu Hukum; Alumni, Bandung; 1991, hlm 325; Melalui buku Imam Syaukani; A. Ahsin Thohari; Dasar-Dasar Politik Hukum, PT Raja Grafindo Persada, Jakarta.

Dispen AU Perjalanan Navigator TNI AU; Jakarta .Edisi Suara Angkasa

\section{Undang-undang:}

Undang-Undang no. 20 tahun 1982 tentang pokok-pokok pertahanan dan keamanan (Hankam)

Undang-Undang No. 15 tahun 1992 tentang Penerbangan dan penjelasannya

Undang- Undang No 1 tahun 2009 tentang Penerbangan dan penjelasannya

\section{Internett:}

www.google.co.id;Angkasasena.blogspot.c om/ 2008/06/prinsip-prinsipdalam-kedaulaatan-atas-html;12 Juli 2015. 
www.google.co.id.www.balitbang.kemhan
.go.id/
Pemberdayaan

Penerbangan- Domestik- Dalam -

Rangka -Memonitor- Wilayah -

NKRI

www.google.co.id;www.geomatika.its.ac.i

d/lang/archives/774; 13 juli 2015 